\title{
Peran Mata Pelajaran PKN Dalam Membangun Karakter Anak Sekolah Dasar Pada Kehidupan Sosial
}

\author{
Moch Lucky Winandar ${ }^{1}$, Dinnie Anggraeni Dewi ${ }^{2}$ \\ Program Studi Konsep Dasar PKN, Universitas Pendidikan Indonesia Kampus Cibiru \\ Jl. Pendidikan No.15, Cibiru Wetan, Cileunyi, Bandung, Jawa Barat 40625 \\ Lukiwinandar09@upi.edu
}

\begin{abstract}
The purpose of this study was to find the role of Pkn subjects in building the character of elementary school children in their social life. And this research is based on researchers' anxiety about the character of the nation's next generation, especially in elementary school children who are starting to deteriorate and deviate from social norms. The number of cases of this deviation is caused by the low character of the nation's successor. There are several factors that cause social deviation, among others, namely; themselves, the role of the family in educating children, and the environment. This shows that the existence of Civics plays an important role in shaping the personality of the nation's future generations. Our lessons are always verbal and only oriented to mastering the content of Civics subjects. The results of observations of daily learning practices show that learning is focused so that students can master the information contained on the topic, then assess the level of mastery of these students. The relationship between teaching materials and everyday life and how to use them to solve problems in life received less attention. Learning seems to be separate from everyday life, so that students do not understand the benefits of what they have learned.
\end{abstract}

Keywords: Citizenship Education, Character Education, Students, National Character, Social Life.

\begin{abstract}
Abstrak
Tujuan penelitian ini yaitu untuk menemukan peran mata pelajaran Pkn dalam membangun karakter anak sekolah dasar dalam kehidupan sosialnya. Dan penelitian ini berlatarkan dari keresahan peneliti terhadap karakter generasi penerus bangsa terutama pada anak sekolah dasar yang mulai memburuk dan menyimpang dari norma sosial. Banyaknya kasus-kasus penyimpangan ini diakibatkan oleh rendahnya karakter penerus bangsa tersebut. Ada beberapa faktor yang menyebabkan terjadinya penyimpangan sosial, antara lain yaitu; diri sendiri, peran keluarga dalam mendidik anak, dan lingkungan sekitar. Hal ini menunjukkan bahwa keberadaan PKn memegang peranan penting dalam pembentukan kepribadian generasi penerus bangsa. Pelajaran kita selalu bersifat verbal dan hanya berorientasi pada penguasaan konten mata pelajaran PKn. Hasil observasi praktik pembelajaran sehari-hari menunjukkan bahwa pembelajaran ini difokuskan agar siswa dapat menguasai informasi yang terdapat pada topik tersebut, kemudian menilai tingkat penguasaan siswa tersebut. Hubungan antara bahan ajar dan kehidupan sehari-hari serta bagaimana menggunakannya untuk memecahkan masalah dalam kehidupan kurang mendapat perhatian. Pembelajaran seolah-olah terpisah dari kehidupan sehari-hari, sehingga siswa tidak memahami manfaat dari apa yang telah dipelajari.
\end{abstract}

Kata kunci: PKn, Pendidikan Karakter, Siswa, Karakter Bangsa, Kehidupan Sosial.

Copyright (c) 2021 Moch Lucky Winandar, Dinnie Anggraeni

Corresponding author: Moch Lucky Winandar

Email Address: Lukiwinandar09@upi.edu (Jl. Pendidikan No.15, Cibiru, Wetan, Cileunyi, Bandung)

Received 22 March 2020, Accepted 24 April 2020, Published 30 April 2021

\section{PENDAHULUAN}

Pancasila dan pendidikan kewarganegaraan memegang peranan dan fungsi yang penting dalam menanamkan nilai-nilai ideologis yang terkandung dalam Pancasila. Di antaranya, nilai-nilai dasar kemanusiaan dan keadilan tidak diragukan lagi menjadi dasar dari konsep kewarganegaraan global, yang niscaya membantu tujuan pendidikan kewarganegaraan. Dalam rangka meningkatkan skill murid dalam hal civic, metode ini memiliki peran yang penting. Mata Pelajaran Pendidikan Kewarganegaraan tujuan untuk mengembangkan siswa menjadi warga negara yang baik yang 
memiliki rasa kebanggaan terhadap negara Indonesia, cinta tanah air, jujur, disiplin, tanggung jawab, santun, peduli, dan percaya diri dalam berinteraksi di lingkungan rumah, sekolah, dan sekitarnya serta berbangsa dan bernegara (Supriyanto, Anton. 2018: 116). Berdasarkan tujuan tersebut, Mata Pelajaran Pendidikan Kewarganegaraan sebagai wahana untuk membangun karakter generasi penerus bangsa.

Undang-undang nomor 20 tahun 2003 tentang sistem pendidikan nasional menyatakan bahwa setiap jenis, jalur, dan jenjang pendidikan harus mencakup pendidikan bahasa, pendidikan agama, dan pendidikan kewarganegaraan. Hal ini menunjukkan bahwa pendidikan kewarganegaraan memegang peranan penting dalam pembentukan kepribadian generasi muda, terutama pada anak usia sekolah dasar.

Terwujudnya tujuan pembelajaran tidak terlepas dari peran utama guru. Guru tidak hanya dituntut untuk menyampaikan ilmu, tetapi juga harus mampu menciptakan suasana belajar yang bermanfaat agar proses pembelajaran dapat terlaksana secara aktif. Berdasarkan pertimbangan tersebut maka diperlukan metode pembelajaran yang memungkinkan siswa untuk berpartisipasi secara utuh, sehingga kekuatan belajar mengajar tidak hanya didominasi oleh siswa tertentu saja.

\section{METODE}

Tempat dan waktu penelitian ini tidak dilaksanakan pada satu tempat ataupun waktu yang bersamaan dikarenakan pada saat ini sedang terjadi pandemi Covid-19, sehingga dalam penelitian ini tidak memungkinkan untuk terjun langsung ke lapangan. Sehingga penulis hanya melakukan penelitian pada beberapa anak yang ada dilingkungan sekitar. Dalam penelitian ini juga penulis melakukan kajian kritis berdasarkan studi pustaka dan penulis menganalisis atas fenomena eksistensi mata pelajaran PKn dalam lingkup sekolah dasar.

Penelitian ini menggunakan metode pendekatan kualitatif dengan metode studi deskriptif. Teknik yang digunakan dalam pengumpulan data yaitu dilakukan dengan cara observasi partisipatif, wawancara, studi dokuentasi, dan studi literatur. Penelitian ini dilakukan untuk mendeskripsikan peran mata pelajaran PKn dalam menumbuhkan karakter anak sekolah dasar dalam kehidupan sosial.

\section{HASIL DAN PEMBAHASAN}

Dalam pelaksanaannya, PKn yang diajarkan guru kepada siswa sudah memuat peranan yang baik dalam menumbuhkan karakter siswa sebagai generasi penerus bangsa seperti pendidikan nilai moral, politik, hukum, dan bela negara. Dan dengan adanya pendidikan tersebut secara tidak langsung guru telah mendidik anak untuk cinta terhadap tanah air (Izma, T. Yolanda, V., 2019). Karakter sopan santun anak merupakan sifat yang sudah sesuai dengan norma yang berlaku dalam kehidupan sosial dan sudah menjadi ciri khas bagi seseorang. Penanaman nilai sopan santun harus ditanamkan dalam diri anak oleh orang tua dan guru sejak dini. Dalam pembentukan karakter anak $\mathrm{SD}$, diperlukan adanya pengolahan atau perencanaan penyajian materi PKn yang dilakukan oleh guru 
di sekolah agar dalam menyampaikan materi tersebut bisa efektif dan efisien, sehingga manfaat dari mata pelajaran PKn dapat dirasakan oleh guru maupun siswa.

Sebagai peran yang sangat penting dalam bidang pendidikan, pendidikan kewarganegaraan sudah memperkenalkan materi yang berkaitan dengan karakter dan nilai-nilai suatu negara. Untuk kemajuan bangsa, beberapa peran yang menjadi tolak ukur perkembangan generasi muda, yaitu sebagai berikut :

1. Religious : Mengikuti sikap atau ajaran agama yang dianutnya, dan tidak meremehkan agama lain atau kita harus bersikap toleran terhadap agama lain. Dengan karakter ini, diharapkan dapat menjadi landasan nilai, moral dan etika dalam bertindak.

2. Jujur : Tindakan menjadikan diri sendiri agar orang lain dapat mempercayainya, baik dalam perkataan, perbuatan, dan pekerjaan berdasarkan kerja keras. Dengan menjadi orang yang jujur, orang lain tidak akan salahpaham dan benci sehingga saling menuduh, dan orang lain tidak akan membenci karena dibohongi.

3. Tanggung jawab : Tanggung jawab ada dalam setiap tindakan yang diambil, yang akan menunjukkan bahwa orang tersebut harus bertanggung jawab atas tugas tersebut dan mampu menanggung konsekuensi dari tindakannya.

4. Toleransi : Adanya sikap dan tindakan menghormati setiap perbedaan. Toleransi akan memudahkan setiap orang untuk berbaur satu sama lain tanpa diskriminasi.

5. Disiplin : Patuhi semua aturan atau regulasi yang berlaku. Ini menunjukkan bahwa individu tersebut sangat menghargai dan mematuhi setiap aturan yang disepakati.

6. Kerja keras : Dengan bekerja keras dalam setiap tindakan, kemandirian, optimisme dan rasa percaya diri akan menunjukkan bahwa orang ini berkarakter dan layak diajak bekerja sama.

7. Kreatif : Melalui pemikiran kreatif dan kritis, dia akan berperilaku sebagai orang yang cerdas. Akan menghindari plagiarisme dan menghasilkan sesuatu yang lebih inovatif.

8. Demokratis : Memperhatikan pemikiran, dan perilaku diri sendiri dan orang lain dengan hak dan kewajiban yang sama. Ketahui apa yang lebih penting dan apa yang harus dilakukan terlebih dahulu.

9. Semangat kebangsaan dan cinta tanah air : Hal ini diperlukan, karena jika tidak ada kesadaran kebangsaan, semangat kebangsaan, dan kecintaan pada tanah air, maka suatu bangsa tidak bisa terwujud jika tidak ada warga, karena kebangsaan suatu bangsa bersumber dari warganya.

10. Peduli lingkungan dan social : Cerminan kepedulian terhadap lingkungan dan masyarakat akan menjadikan setiap orang sebagai pribadi yang dihormati, dicintai dan dilindungi oleh lingkungan sosial.

Pembelajaran adalah upaya membantu siswa atau beberapa siswa menyadari perubahan struktur kognitif melalui pemahaman. Psikologi humanistik, pembelajaran merupakan upaya guru untuk menciptakan suasana belajar yang menyenangkan (enjoy learning), yang menjadikan siswa dikenal 
sebagai pembelajaran (Darsono, Max. 2001: 24-25). Sedangkan konsep pembelajaran menurut teori sibernetika adalah pengolahan informasi, seolah-olah teori tersebut memiliki kesamaan dengan teori kognitif, yang lebih menekankan pada proses belajar daripada hasil belajar (Budiningsih, Asri C. 2005: 80-81). Proses pembelajaran memang penting dalam cybernetics, namun yang lebih penting adalah sistem informasi olahan yang akan dipelajari siswa. Informasi ini akan menentukan kemajuan proses pembelajaran, yang sebagian besar bergantung pada sistem informasi yang dipelajari.

Pendidikan karakter merupakan salah satu bentuk kegiatan manusia, diantaranya adalah kegiatan pendidikan untuk generasi penerus (Kusuma A, Doni. 2007: 3). Tujuan pendidikan karakter adalah terus menerus membentuk perbaikan diri individu dan melatih kemampuan diri untuk meningkatkan kehidupan.

Istilah pendidikan kewarganegaraan telah diakui secara legal formal dalam sistem pendidikan di Indonesia. Istilah pendidikan kewarganegaraan merupakan terjemahan dari terminologi bahasa inggris "citizenship education" atau "civic education". Selain diterjemahkan sebagai pendidikan kewarganegaraan, ada yang menggunakan istilah "pendidikan kewarganegaraan" (Azumardi Azra, 2003).

Secara umum, tujuan pendidikan kewarganegaraan di semua negara adalah membentuk warga negara yang baik atau "warga negara yang baik". Tujuan utamanya adalah untuk "menjadikan warga negara ini warga negara". Menurut Buku Guru Mata Pelajaran PPKn (2016) disebutkan bahwa tujuan mata pelajaran PPKn pada jenjang pendidikan dasar dan menengah adalah untuk mengembangkan potensi peserta didik di berbagai bangsa. Dapat disimpulkan bahwa pendidikan kewarganegaraan pada hakikatnya merupakan program pendidikan yang meliputi pembahasan tentang kebangsaan, kewarganegaraan, demokrasi, hak asasi manusia, dan masyarakat sipil, serta penerapan prinsip demokrasi dan humanisme dalam penyelenggaraan pendidikan.

Pembelajaran pendidikan kewarganegaraan di sekolah dasar adalah mata pelajaran yang penuh dengan muatan afektif. Untuk memaksimalkan sikap emosional siswa, proses pembelajaran hendaknya tidak hanya dari buku, akan tetapi seorang guru harus memberikan pengajaran secara langsung kepada anak dengan memberikan contoh tentang sebuah sikap yang baik. Melakukan pembelajaran secara langsung dapat memberikan pengalaman belajar nyata yang didapatkan oleh siswa. Lingkungan merupakan salah satu sumber daya yang dapat digunakan dalam pembelajaran PKn di Sekolah Dasar. Lingkungan yang dapat dimanfaatkan oleh warga sekolah dasar untuk belajar adalah lingkungan alam, sosial dan budaya. Pembelajaran Pendidikan Kewarganegaraan pada dasarnya adalah proses interaksi antara siswa dan lingkungan, yang mengarah pada perubahan perilaku ke arah yang lebih baik. Pembelajaran Pendidikan Kewarganegaraan merupakan realisasi dari kurikulum, yang menuntut guru untuk berperan aktif dalam kegiatan menciptakan dan mengembangkan siswa sesuai dengan rencana yang dibuat. Ketika siswa tidak mampu mengembangkan kemampuan dasar, baik itu menghentikan kegiatan pembelajaran, mengubah metode atau mengulang pelajaran sebelumnya, guru harus dapat mengambil keputusan berdasarkan penilaian 
yang sesuai. Guru harus menguasai prinsip-prinsip pembelajaran, memilih dan menggunakan metode pembelajaran. Pendidikan kewarganegaraan berperan untuk melatih warga negara khususnya generasi penerus bangsa yang bermanfaat bagi kehidupan bernegara dan berbangsa. Guna membangun kesadaran bela negara dan meningkatkan kecintaan pada tanah air, pendidikan kewarganegaraan bagi generasi penerus sangat penting. Karena generasi penerus akan menjadi pemimpin masa depan negara. Dalam pendidikan kewarganegaraan, siswa sebagai geerasi penerus selalu dibekali dengan hal-hal yang dapat meningkatkan rasa nasionalismenya. Dalam pendidikan kewarganegaraan diutamakan pada pemahaman dan pembinaan sikap dan perilaku yang berlandaskan Pancasila dan nilai-nilai budaya bangsa. Sebagai tujuan utama dari pendidikan kewarganegaraan, semua itu untuk menumbuhkan wawasan dan pengetahuan bangsa, kecintaan pada tanah air dan berlandaskan budaya nasional, pemahaman tentang nusantara, serta sikap dan perilaku generasi penerus ketahanan nasional. Melalui pendidikan kewarganegaraan, generasi bangsa Indonesia diharapkan mampu memahami, menganalisis dan menjawab permasalahan yang dihadapi masyarakat, bangsa, dan negara, yang berkelanjutan dan sejalan dengan cita-cita dan tujuan nasional yang dituangkan dalam Pembukaan UUD 1945.

Tentunya lembaga pendidikan yang bisa memahami keadaan tidak akan mengabaikan pentingnya kebangsaan dan media pendidikan kewarganegaraan. Berupaya dan dimungkinkan untuk berkontribusi melalui pendidikan, serta dapat memberikan pengalaman untuk mencapai karakter yang diinginkan.

Wynne (dikutip oleh Zuchdi, Darmiyati. 2009) mengemukakan bahwa kata "character" diambil dari bahasa Yunani yang berarti "mark", dan istilah tersebut lebih menitikberatkan pada upaya mengaplikasikan nilai kebaikan dalam bentuk tindakan atau perilaku. tingkah laku. Selain itu, kata Wynne, ada dua definisi karakter: pertama, karakter menunjukkan perilaku seseorang; jika seseorang berperilaku tidak jujur, kejam atau rakus, maka tentu saja orang tersebut menunjukkan perilaku buruk atau karakter buruk; sebaliknya, jika seseorang menunjukkan kejujuran tentu saja orang tersebut menunjukkan akhlak yang mulia. Kedua, istilah "karakter" sangat erat kaitannya dengan "kepribadian". Jika perilaku pendatang baru sesuai dengan prinsip moral, ia dapat disebut sebagai "orang yang berkarakter" (Zuchdi, Darmiyati. 2009). Oleh karena itu, menurut Lickona (1992), pendidikan karakter yang baik tidak hanya harus melibatkan "memahami kebaikan" tetapi juga "keinginan untuk kebaikan", "cinta kebaikan" dan "berbuat baik".

Lahirnya pendidikan karakter dapat dikatakan sebagai upaya untuk mencapai kehidupan spiritual yang ideal. Tujuan utama pendidikan karakter adalah untuk membentuk karakter itu sendiri, karena karakter merupakan evaluasi terhadap seseorang atau individu, dan karakter juga dapat disatukan atas kekuatan dalam segala situasi. Pendidikan karakter juga dapat digunakan sebagai strategi untuk menghadapi perubahan pengalaman, sehingga dapat membentuk jati diri yang kuat bagi setiap orang. Dalam hal ini terlihat bahwa tujuan pendidikan karakter adalah untuk membentuk sikap yang dapat membawa kita maju tanpa harus bertentangan dengan norma yang berlaku. Pendidikan 
karakter juga digunakan sebagai sarana sosialisasi karakter yang harus dilakukan oleh setiap orang agar menjadi masyarakat yang memiliki manfaat sebesar-besarnya bagi lingkungan sekitarnya.

Di sini dapat diasumsikan bahwa objek atau sasaran pendidikan karakter biasanya yaitu seluruh warga negara terutama peserta didik dari berbagai jenis dan jenjang pendidikan, bagi siswa dikatakan demikian. Sebagai generasi penerus bangsa, mereka semua adalah warga negara hipotetis, yakni warga negara yang "belum selesai", karena masih harus mengenyam pendidikan agar menjadi warga negara dewasa yang memahami hak dan kewajibannya. Di sisi lain, masyarakat memang menginginkan generasi muda dipersiapkan menjadi warga negara yang baik dan mampu berpartisipasi dalam kehidupan masyarakat dan negaranya, bertanggung jawab, santun, beradab, menghormati orang lain dan peran lainnya. Salah satu media yang paling tepat untuk menghidupkan kembali peran tersebut adalah Pendidikan Kewarganegaraan, dalam arti nilai-nilai dalam pendidikan kewarganegaraan diwujudkan dalam diri warga negara melalui proses integrasi.

Apabila nilai pendidikan karakter diwujudkan melalui Pendidikan Kewarganegaraan, maka dapat dikatakan bahwa nilai peran warga meliputi nilai karakter pokok. Nilai-nilai utama kewarganegaraan adalah melatih peserta didik dengan nilai agama, kejujuran, kecerdasan, ketangguhan, demokrasi dan kepedulian. Sedangkan nilai-nilai utama kewarganegaraan adalah melatih siswa dengan ciri-ciri sebagai berikut: nasionalis, taat pada aturan sosial, menghargai kebhinekaan, sadar akan hak dan kewajiban diri sendiri dan orang lain, bertanggung jawab, berpikir logis, kritis, kreatif dan inovatif, dan mandiri. Nilai peran utama tersebut dapat dikembangkan lebih luas untuk meningkatkan fungsi warga negara sebagai pendidikan karakter.

\section{KESIMPULAN}

Pancasila dan pendidikan kewarganegaraan memegang peranan dan fungsi yang sangat penting dalam menanamkan nilai-nilai ideologis Pancasila. Di antaranya, nilai-nilai dasar kemanusiaan dan keadilan tidak diragukan lagi menjadi dasar dari konsep kewarganegaraan global, yang niscaya membantu tujuan pendidikan kewarganegaraan. Dalam rangka meningkatkan skill siswa dalam civic, metode ini memiliki peran yang berarti.

Pembelajaran Pendidikan Kewarganegaraan pada dasarnya adalah proses interaksi antara siswa dan lingkungan, yang mengarah pada perubahan perilaku ke arah yang lebih baik. Pembelajaran Pendidikan Kewarganegaraan merupakan realisasi dari kurikulum, yang menuntut guru untuk berperan aktif dalam kegiatan menciptakan dan mengembangkan siswa sesuai dengan rencana yang dibuat. Ketika siswa tidak mampu mengembangkan kemampuan dasar, baik itu menghentikan kegiatan pembelajaran, mengubah metode atau mengulang pelajaran sebelumnya, guru harus dapat mengambil keputusan berdasarkan penilaian yang sesuai. Guru harus menguasai prinsip-prinsip pembelajaran, memilih dan menggunakan metode pembelajaran.

Tujuan dari pendidikan kewarganegaraan di semua negara adalah membentuk warga negara yang baik atau "good citizen". Tujuan utamanya adalah "mewarganegarakan" warga negara di negara 
tersebut. Menurut Buku Guru mata pelajaran PPKn (2016) dikatakan bahwa tujuan mata pelajaran PPKn pada jenjang pendidikan dasar dan menengah adalah mengembangkan potensi peserta didik dalam seluruh dimensi kewarganegaraan. Dapat disimpulkan bahwa pendidikan kewarganegaraan pada hakikatnya merupakan program pendidikan yang memuat pembahasan tentang kebangsaan, kewarganegaraan, demokrasi, hak asasi manusia dan masyarakat sipil, serta menerapkan prinsip demokrasi dan humanisme dalam penyelenggaraan pendidikan.

Apabila nilai pendidikan karakter diwujudkan melalui Pendidikan Kewarganegaraan, maka dapat dikatakan bahwa nilai peran warga meliputi nilai karakter pokok. Nilai-nilai utama kewarganegaraan adalah melatih peserta didik dengan nilai agama, kejujuran, kecerdasan, ketangguhan, demokrasi dan kepedulian.

Dari seluruh pembahasan diatas dapat diketahui bahwa pendidikan karakter ini sangat penting, terutama bagi anak sekolah dasar sebagai generasi penerus bangsa. Dengan adanya pembelajaran pendidikan kewarganegaraan diharapkan bisa menjadi sebuah solusi atau pengajaran terhadap permasalahan yang terjadi di Indonesia mengenai karakter generasi penerus bangsa. Oleh karena itu dengan adanya pembelajaran Pendidikan Kewarganegaraan bagi anak SD, diharapkan bisa menjadikan generasi penerus bangsa menjadi manusia yang cerdas dan berkarakter yang baik.

\section{UCAPAN TERIMA KASIH}

Terimakasih saya ucapkan kepada Ibu Dinie Anggraeni selaku dosen pengampu mata kuliah Konsep Dasar PKN dan teman-teman kelas 2B PGSD yang telah membantu saya dalam menuliskan artikel ini.

\section{REFERENSI}

Azumardi Azra, (2003). Pendidikan Kewarganegaraan (Civic Education): Demokrasi, Hak Asasi Manusia dan Masyarakat Madani. Jakarta: Prenada

Budiningsih, Asri C. 2005. Belajar dan Pembelajaran. Jakarta: Rineka Cipta.

Darsono, Max. 2001. Belajar dan Pembelajaran. Semarang: IKIP Semarang Press.

Izma, T. Yolanda, V. (2019). "Peran Pendidikan Kewarganegaraan Dalam Membangun Karakter Bangsa". [Online]. https://jurnal.univpgri-palembang.ac.id/index.php/didaktika/article/ view/2419. Diakses pada 30 Maret 2021.

Kusuma A, Doni. (2007). Pendidikan Karakter. Jakarta: Grasindo.

Lickona. (1992). Educating From Character How Our School Can Teach Respect and Responsibility.

New York-Toronto-London-Sidney-Auckland: Bantan Books Mahbubi. M., 2012,

Pendidikan Karakter, Yogyakarta: Pustaka Ilmu.

Pemerintah Republik Indonesia. (2003). Undang-Undang Republik Indonesia Nomor 20 Tahun 2003

Tentang Sistem Pendidikan Nasional.

Supriyanto, Anton. (2018). Upaya Untuk Meningkatkan Keberanian Berpendapat Dan Prestasi Belajar Melalui Penerapan Model Dilema Moral Mata Pelajaran PPKn. Jurnal Bhineka Tunggal Ika:

Kajian Teori dan Praktik PKn. Volume 5, No.2 , November 2018, pp. 116-122.

Zuchdi, Darmiyati. (2009). Pendidikan Karakter. Yogyakarta: UNY Press. 